\title{
Second Ebola patient is treated in UK
}

\author{
Anne Gulland
}

London

A UK nurse who contracted the Ebola virus in Sierra Leone has been admitted to the high level isolation unit at the Royal Free Hospital in London.

The patient has been named as Pauline Cafferkey, a public health nurse at Blantyre Health Centre in South Lanarkshire. She returned to her home late in the evening on Sunday 28 December, having taken a flight from Casablanca to London Heathrow and then transferred to Glasgow. She was admitted to the Brownlee Unit for Infectious Diseases at Glasgow's Gartnavel General Hospital early on 29 December after feeling unwell.

In line with the UK protocol for Ebola cases Cafferkey, who has been writing a diary of her time in Sierra Leone for the Scotsman newspaper, was transferred by military plane to the Royal Free Hospital's infectious diseases unit in the early hours of 30 December. This is the same unit that treated the United Kingdom's only other patient with the Ebola virus-Will Pooley, a nurse who was transferred there directly after testing positive for the disease in Sierra Leone.

A hospital spokesman did not say what treatment Cafferkey would receive. Pooley received the experimental drug ZMapp, supplies of which are now exhausted. No drugs are currently licensed to treat the virus, although clinical trials of Ebola treatments started in west Africa in early December. ${ }^{1}$ Cafferkey will be treated by a team of specially trained doctors, nurses, and laboratory staff, and entry to the unit will be restricted to just those staff.

Public Health England has said that the risk of infection to the wider public and other passengers who travelled with Cafferkey is "extremely low," but it is arranging for all passengers and crew who were on the flight from Casablanca to Heathrow to be given health information, and it will contact and follow up passengers who were sitting near Cafferkey. Health Protection Scotland will carry out similar measures for passengers who were on the flight from Heathrow to Glasgow.

Sally Davies, chief medical officer for England, said that the patient had been doing a "fantastic job saving lives." She added, "We have robust, well developed and well tested NHS systems for managing unusual infectious diseases when they arise, supported by a wide range of experts. The UK system was prepared, and reacted as planned, when this case of Ebola was identified."

Meanwhile, the $\mathrm{BBC}$ has reported that returning healthcare workers are being tested for the disease in Cornwall and Aberdeen. Paul Cosford, medical director of Public Health England, told $B B C$ News that the testing was part of a range of measures to "keep the UK safe."

Over the past three to four months around 150 people from the UK have been tested for the disease, and Public Health England remains in contact with health workers who are returning from west Africa. "It's something we are doing often on a day to day, week to week basis," said Cosford.

A spokesman for the Department of Health said that the patient had been screened twice on her journey to the UK-on her exit from Sierra Leone and on her entry to UK. He said that screening was unlikely to pick up cases of Ebola and was more about giving information to potential carriers of the virus.

Infectious disease experts have agreed that the risk to the wider public is low. Tom Solomon, director of the Institute of Infection and Global Health at the University of Liverpool, said, "We would hope that, because this patient appears to have come to medical attention relatively early, the risks to others are very small; also, because [she has] been hospitalised early, [she has] a better chance of getting through this terrible illness.

"Although there is no established antivirus treatment, we do know that supportive treatment, to maintain hydration and stop patients becoming acidic, is vital."

The latest situation report from the World Health Organization, dated 24 December, noted a total of 20081 cases of Ebola virus disease so far, including 7842 deaths. Of these cases, 9409 have been in Sierra Leone, 7977 in Liberia, and 2695 in Guinea.

1 Gulland A. Clinical trials of Ebola therapies to begin in December. BMJ 2014;349:g6827.

Cite this as: BMJ 2014;349:g7861

๑ B BMJ Publishing Group Ltd 2014 
Figure

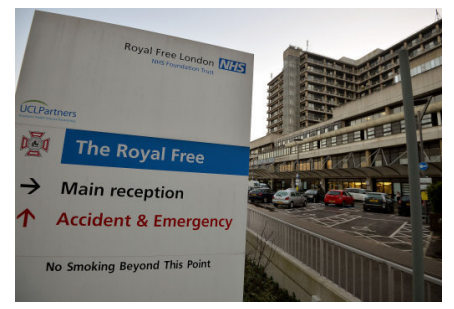

[lmage: John Stillwell/PA] 